\title{
The odyssey of the Cache Creek terrane, Canadian Cordillera: Implications for accretionary orogens, tectonic setting of Panthalassa, the Pacific superwell, and break-up of Pangea
}

\author{
S.T. Johnston ${ }^{\mathrm{a}, *}$, G.D. Borel ${ }^{\mathrm{b}}$ \\ ${ }^{a}$ SEOS University of Victoria, PO Box 3055 STN CSC, Victoria BC, Canada V8W 3P6 \\ ${ }^{\mathrm{b}}$ Museum of Geology, Anthropole, CH-1015 Lausanne, Switzerland
}

Received 9 March 2006; received in revised form 29 October 2006; accepted 2 November 2006

Available online 5 December 2006

Editor: R.D. van der Hilst

\begin{abstract}
The Cache Creek terrane (CCT) of the Canadian Cordillera consists of accreted seamounts that originated adjacent to the Tethys Ocean in the Permian. We utilize Potential Translation Path plots to place quantitative constraints on the location of the CCT seamounts through time, including limiting the regions within which accretion events occurred. We assume a starting point for the CCT seamounts in the easternmost Tethys at $280 \mathrm{Ma}$. Using reasonable translation rates $(11 \mathrm{~cm} / \mathrm{a})$, accretion to the StikiniaQuesnellia oceanic arc, which occurred at about $230 \mathrm{Ma}$, took place in western Panthalassa, consistent with the mixed Tethyan fauna of the arc. Subsequent collision with a continental terrane, which occurred at about $180 \mathrm{Ma}$, took place in central Panthalassa, $>4000 \mathrm{~km}$ west of North America yielding a composite ribbon continent. Westward subduction of oceanic lithosphere continuous with the North American continent from 180 to 150 Ma facilitated docking of the ribbon continent with the North American plate.

The paleogeographic constraints provided by the CCT indicate that much of the Canadian Cordilleran accretionary orogen is exotic. The accreting crustal block, a composite ribbon continent, grew through repeated collisional events within Panthalassa prior to docking with the North American plate. CCT's odyssey requires the presence of subduction zones within Panthalassa and indicates that the tectonic setting of the Panthalassa superocean differed substantially from the current Pacific basin, with its central spreading ridge and marginal outward dipping subduction zones. A substantial volume of oceanic lithosphere was subducted during CCT's transit of Panthalassa. Blanketing of the core by these cold oceanic slabs enhanced heat transfer out of the core into the lowermost mantle, and may have been responsible for the Cretaceous Normal Superchron, the coeval Pacific-centred mid-Cretaceous superplume event, and its lingering progeny, the Pacific Superswell. Far field tensile stress attributable to the pull of the slab subducting beneath the ribbon continent from 180 to 150 Ma instigated the opening of the Atlantic, initiating the dispersal phase of the supercontinent cycle by breaking apart Pangea. Docking of the ribbon continent with the North American plate at 150 Ma terminated the slab pull induced stress, resulting in a drastic reduction in the rate of spreading within the growing Atlantic Ocean. (C) 2006 Elsevier B.V. All rights reserved.
\end{abstract}

\footnotetext{
* Corresponding author.

E-mail addresses: stj@uvic.ca (S.T. Johnston), Gilles.Borel@unil.ch (G.D. Borel).
} 


\section{Introduction}

Accretionary orogens form at long-lived convergent margins, and consist of a complex collage of accreted crust and lithosphere (terranes), that include arcs, oceanic plateaux, and seamounts. Such orogens host the bulk of the Earth's orogenic gold and volcanogenic massive sulphides deposits, are stitched together and onlapped by post-tectonic granitoid intrusions and sedimentary basins, respectively, and are commonly inferred to be the sites of construction of continental lithosphere $[1,2]$. Establishing the processes responsible for the development and evolution of accretionary orogens, and quantifying the rate of continental growth within such orogens remains, therefore, of significant tectonic and economic interest.

The Canadian Cordillera (Fig. 1) developed along the west margin of the Pangea supercontinent (Fig. 2) during its break-up, faced east toward the Panthalassa superocean, and is commonly cited as a prime example

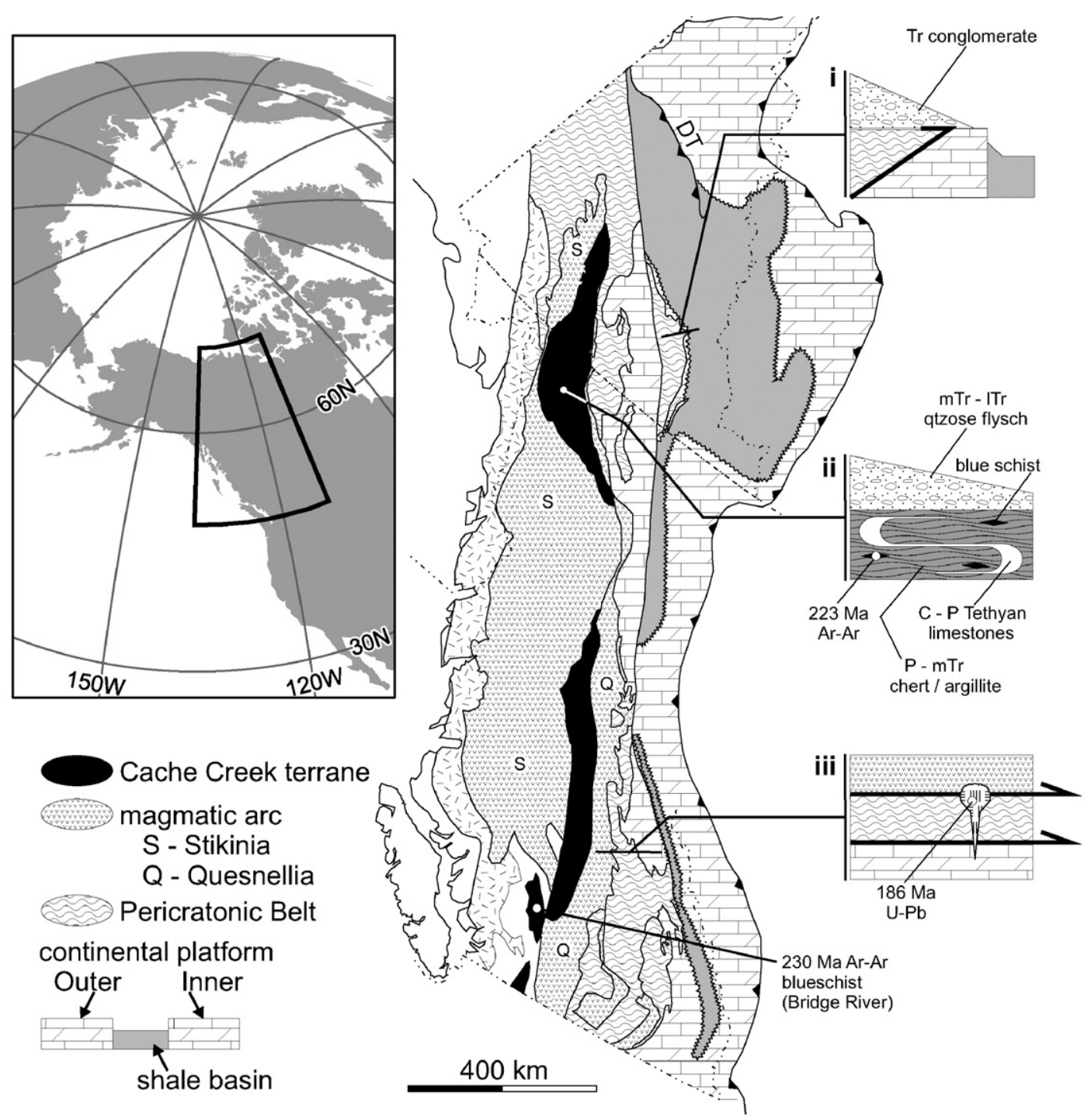

Fig. 1. Tectonic map of the Canadian Cordillera, location indicated on index map at top left. Schematic cross-sections at right show (i) Triassic conglomerate unconformably overlying the thrust that places pericratonic belt crystalline rocks on top of the outboard continental platform; (ii) Middle Triassic and younger arc flysch, interpreted to be derived from Stikinia, unconformably overlying folded and metamorphosed (blueschist facies) Cache Creek strata; and (iii) 186 Ma plutons intruding and stitching together previously imbricated strata of the Quesnellia arc terrane, the pericratonic belt and the outboard continental platform. Cooling ages from Cache Creek and correlative blueschists indicated (references in text). DT - Dawson thrust. 

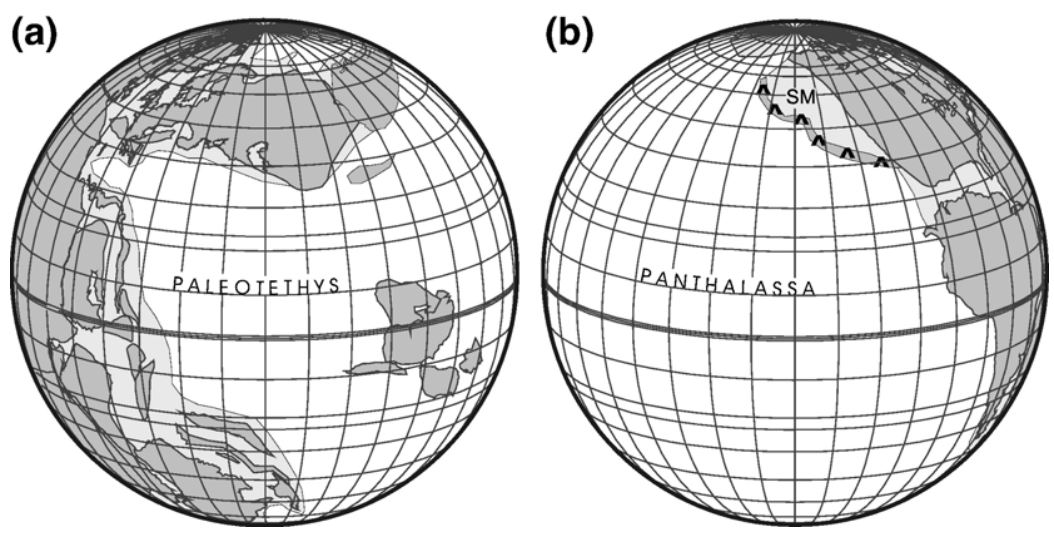

Fig. 2. Permian paleogeography, after Stampfli and Borel [78], with continental regions in grey and light grey. (a) The northern Laurasian and southern Gondwanan components of Pangea separated by the eastward widening Paleotethys. Continental blocks that now form South China occurs along the eastern margin of Tethys and separate it from Panthalassa to the east. (b) The opposite side of the Earth, showing Panthalassa and the west margin of Pangea. The commonly interpreted location of the Stikinia-Quesnellia arc, taken from Mihalynuk et al. [16], is indicated by a grey band ornamented with inverted V symbols (volcanoes) and is separated from the continent by the 0 to $1500 \mathrm{~km}$ wide Slide Mountain (SM) marginal basin.

of an accretionary orogen $[3,4]$. Hence the orogen provides us with a record of plate margin processes involved in the break-up phase of a supercontinent cycle, and presents us with an opportunity to better understand the processes involved in supercontinent dispersal and superocean tectonics. The Pacific basin is the remains of Panthalassa, and its current geometry and character may, therefore, owe much to the geometry and fate of the oceanic plates that floored Panthalassa. Oceanic terranes preserved within the Cordillera may, therefore, provide us with constraints on the tectonics and evolution of the Panthalassa superocean, and clues as to current tectonic setting and thermal structure of the Pacific basin.
The Cache Creek terrane is an accretionary complex within the Canadian Cordillera. The complex includes the uppermost portions of upper Paleozoic seamounts and oceanic plateau. Sedimentary rocks deposited on these seamounts are characterized by Tethyan fauna [5], implying an origin within the Tethys, the internal ocean that separated the northern (Laurasia) and southern (Gondwana) portions of Pangea, and which opened eastward into the westernmost portion of Panthalassa (Fig. 2). The Cache Creek seamounts, therefore, originated on the opposite side of Panthalassa from the Cordilleran accretionary orogen. Their odyssey, crossing the Panthalassa superocean, has never been explored as a constraint on Panthalassan tectonics, and is the focus of our paper. (a)

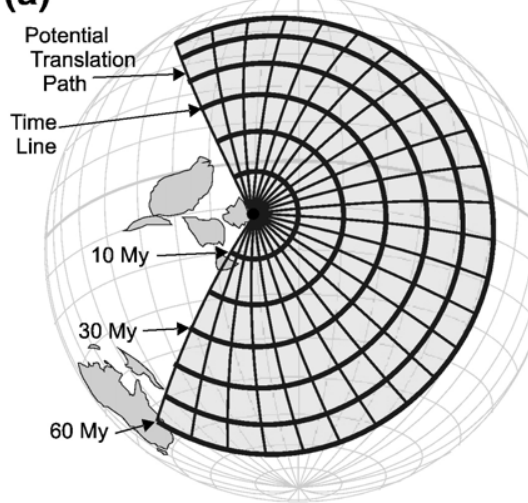

(b)

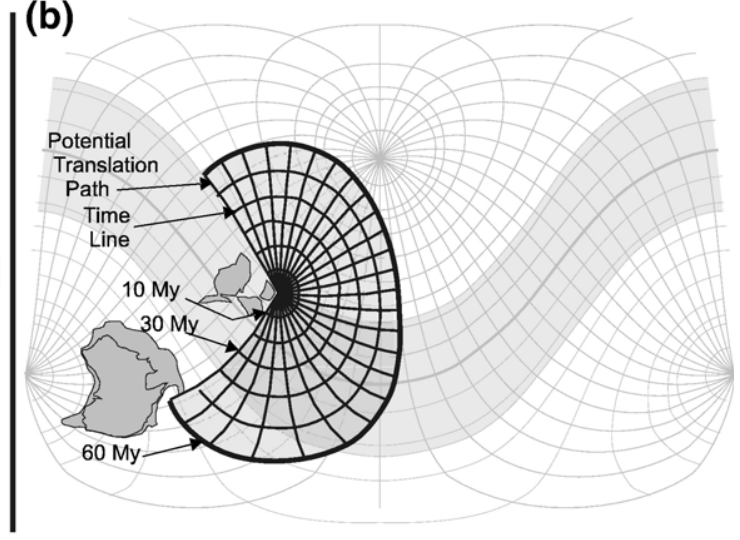

Fig. 3. Potential Translation Path plots, constructed using GMAP [79], on (a) an orthogonal projection, and (b) a Mercator projection. Potential Translation Paths are shown as portions of great circles radiating out from an assumed starting point. Small circles perpendicular to the Potential Translation Paths are time lines that show the maximum possible distance travelled at a given rate $(11 \mathrm{~cm} / \mathrm{a})$ in $10 \mathrm{~m} . \mathrm{y}$. increments. Together, the translation paths and time lines define a velocity net that is shaded in grey. 
We review stratigraphic, geochemical and faunal data that pertain to the origin and accretion history of the Cache Creek seamounts. Potential Translation Path (PTP) plots (Fig. 3) are introduced as a means of placing quantitative constraints on the location of the Cache Creek seamounts through time, including limiting the regions within which accretion events occurred. The translation path of the Cache Creek seamounts (1) yields new insights into the accretionary history of the Cordilleran orogen, (2) aids us in better understanding the plate tectonics of Panthalassa and the role of the superocean in shaping our post-Pangea Earth, and (3) provides us with a means for investigating the role of the Cordillera in the break-up of Pangea.

\section{Terranes and terrane relationships}

The four main terranes of the Canadian Cordillera, from west to east, are (1) the Cache Creek accretionary complex, (2) the Stikinia-Quesnellia arc, (3) the pericratonic belt, and (4) passive margin sequences of the Cordilleran Foreland (Fig. 1) (we ignore the more outboard terranes located along the west margin of the orogen). Here we briefly describe each of these four main terranes and indicate the nature and timing of links between each of the terranes.

\subsection{Cache Creek terrane}

The Cache Creek terrane (Fig. 1) and correlative sequences is an accretionary complex that includes melange belts, mafic-ultramafic volcanic-plutonic complexes, and large intact stratigraphic sequences (up to $75 \mathrm{~km}$ long by $40 \mathrm{~km}$ wide and 1 to $2 \mathrm{~km}$ thick) that consist mostly of shallow water reefal carbonates. The reefal carbonates commonly stratigraphically overlie basalt. Geochemical studies indicate that these basalts are alkalic, compositionally resembling Hawaiian basalts in major and trace elements, and are geochemically classified as Ocean Island basalts or within-plate tholeiites [6-8]. The within-plate character of the basalts is consistent with interpretation of the Cache Creek terrane as consisting of off-scraped seamounts and oceanic plateau with fringing carbonate reefs and banks [9]. The seamounts are assumed to have originated above a hotspot or mantle plume within an ocean basin setting [8]. The seamount basalts are characterized by a DUPAL isotopic signature [10], with elevated ${ }^{208} \mathrm{~Pb} /{ }^{204} \mathrm{~Pb}(37.8-38.6)$ relative to ${ }^{206} \mathrm{~Pb} /{ }^{204} \mathrm{~Pb}(18.1-$ 19.1) and moderate åNd(T) of $\sim 5$ [7]. The Cache Creek terrane is overthrust by and lies in the forearc region of the Stikinia and Quesnellia arcs (Fig. 1), and is interpreted as the accretionary prism that developed during subduction beneath the arcs [11].

Sedimentary rocks of the Cache Creek terrane are characterized by fauna that are exotic with respect to other terranes of the Cordillera and to autochthonous North American strata. The distinct Cache Creek fauna range in age from Upper Carboniferous into the Triassic, and are characterized by the distinct Permian Veerbeekinid (Yabeina) fusulinids [5] that are known elsewhere only from the Tethyan domain of southern Asia. The benthic nature of the fusulinids allows for only limited distribution by currents, and effectively restricts the seamounts to having originated adjacent to other crustal blocks characterized by similar fauna. Additional Eurasian or Tethyan fauna observed in sedimentary rocks of the Cache Creek seamounts include Upper Carboniferous to Triassic sponges, corals, spongiomorphs, brachiopods, bryozoans and other tropical reef organisms [12], as well as conodonts and radiolarian [13]. Based on the Tethyan faunal character, the Cache Creek seamounts are interpreted to have originated within or immediately adjacent to the Tethyan ocean that separated the southerly Gondwanan and northerly Laurasian portions of the supercontinent Pangea (Fig. 2)[5]. Deposition of Upper Carboniferous to Lower Triassic shallow water limestones [14] requires that the Cache Creek terrane remained within the tropics throughout this period.

\subsection{Stikinia-Quesnellia}

The Cache Creek terrane accretionary complex is structurally juxtaposed against the Stikinia (to the west) and Quesnellia (to the east) volcanic arc terranes. Though now on opposite sides of Cache Creek terrane, Stikinia and Quesnellia share a common Paleozoic to early Mesozoic history and are inferred to have originated as a single, continuous magmatic arc that lay to the east of the Cache Creek terrane $[15,16]$. Migration of Stikinia to a position outboard (west) of the Cache Creek terrane is inferred to have occurred during syn- to post-accretion deformation, either as a result of strike-slip displacement [15] or by oroclinal bending [16].

Devonian to Permian carbonate deposition and arc magmatism characterize the Stikinia-Quesnellia magmatic arc [9,17-20]. A basal quartzose turbidite sequence suggests proximity to a continental domain in the Devonian [19,21]. A restricted, condensed sequence of argillite, chert and conglomerate characterizes the Upper Permian to Middle Triassic, deposition of which was followed in the Upper Triassic by arc magmatism and coral reef formation $[18,22]$. 
Stikinia-Quesnellia lack the distinctly Tethyan fauna that characterizes the Cache Creek terrane, and have considerably lower fusulinid species diversity. Permian strata are characterized by schwagerinid fusulinids and additional fauna that are similar to those found in the McCloud Limestone of northern California and Nevada [23]. The McCloud Fauna is distinct from the fauna of coeval North American strata. The degree of separation required to produce this faunal provincialism is commonly assumed to have been $<1000 \mathrm{~km}[24,25]$, and the arcs are inferred to have been separated from the autochthon by a marginal basin [16] or to be autochthonous on North American basement [26](Fig. 2).

Exotic fauna of Eurasian affinity locally characterizes Stikinia and Quesnellia, however, and may point to a more distant origin for the arc. Conodonts of exclusively Eurasian derivation characterize Upper Devonian and Lower Carboniferous strata of Quesnellia and Stikinia, respectively [27]. Permian and Triassic strata are of a mixed faunal realm that includes corals, conodonts and radiolaria that are otherwise unknown outside Tethys [28,29].

Paleomagnetic data constraining the Permian through Jurassic paleolatitude of Stikinia-Quesnellia are limited. Reversed polarity recorded by Permian strata implies a northern hemispheric origin, because during much of the Permian the earth's magnetic field resided in a reversed polarity superchron [30]. Late Triassic and Early Jurassic volcanic rocks yield paleolatitudes, relative to autochthonous North America, that are similar to their current latitude, leading to the suggestion that Stikinia-Quesnellia has been fixed to North America since the Triassic [31]. Stikinia-Quesnellia is, however, characterized by Carnian and Norian sponge reefs that are otherwise unknown outside of tropical Tethyan sequences [28,29], implying that the arc lay within the tropics between 220 and $200 \mathrm{Ma}$.

The Cache Creek seamounts lay on and were conveyed by the slab subducting beneath Stikinia-Quesnellia into the arc. Lower Triassic or earlier accretion of the seamounts [16] is recorded by (1) the on-lap of Lower Triassic and younger arc-derived quartzose flysch onto the Cache Creek carbonates [32,33], (2) post-Upper Permian but pre-Upper Triassic isoclinal folding of Cache Creek strata and associated bedding-parallel foliation development, and (3) blueschist facies metamorphism [11,32]. Blueschist cooling ages of between 220 and $230 \mathrm{Ma}[34,35]$ are consistent with exhumation following Lower Triassic entry into a subduction zone. Upper Permian to Lower Triassic quiescence within the Stikinia-Quesnellia arc may be an upper plate response to seamount and plateau accretion. Locally the Cache
Creek accretionary complex includes Lower Jurassic chert $[14,36]$ implying continued subduction subsequent to seamount accretion. Blueschist facies metamorphism of Cache Creek terrane rocks that yield ages as young as Lower Jurassic [37] further implies continued subduction and exhumation. Seamount accretion did not, therefore, terminate subduction beneath Stikinia-Quesnellia.

\subsection{Pericratonic belt}

A series of pericratonic assemblages lie adjacent to and are structurally juxtaposed against the inboard (continentward) margin of the Stikinia-Quesnellia arc [16]. Locally referred to as the Nisling, Yukon-Tanana and Kootenay terranes, these assemblages are characterized by quartzose rocks and are assumed to have originated as a continental margin. Voluminous Late Devonian, Mississippian, and Permian volcanic and plutonic suites imply subduction beneath the margin and the development of an Andeantype magmatic arc in the middle to upper Paleozoic [38]. Residence adjacent to a subduction zone is further indicated by the presence of blueschists and eclogites yielding cooling ages ranging from the Carboniferous to the Triassic [39]. Imbricated with and lying along the eastern margin of the pericratonic belt are dismembered Upper Devonian to Permian ophiolite, referred to as the Slide Mountain terrane, that is inferred to have originated within a marginal basin that developed landward of the Andean arc assemblages [40](Fig. 2).

The pericratonic belt is overthrust by StikiniaQuesnellia. $186 \mathrm{Ma}$ plutons intrude and stitch together Stikinia-Quesnellia and the pericratonic terranes [41], limiting imbrication to the Early Jurassic or earlier. A magmatic arc (Stuhini-Nicola) consisting of isotopically juvenile mafic volcanic rocks [42], that developed on Stikinia-Quesnellia (and on the previously accreted Cache Creek seamounts) in the Upper Triassic contrasts with coeval quiescence in the pericratonic belt, implying separation of these terranes until the end of the Triassic. The Stuhini-Nicola arc probably provides a record of closure of an oceanic basin separating Stikinia-Quesnellia and the pericratonic belt, with final closure and collision occurring in the latest Triassic-earliest Jurassic. Pliensbachian molasse shed off the collision zone includes clasts of ultra-high pressure garnet peridotite unroofed from depths of 100 to $150 \mathrm{~km}$ depth [43] indicating that the arc-pericratonic belt collision was thick-skinned. Rare Upper Triassic magmatism in the pericratonic belt, for example the Teslin-Taylor Mountain batholith in Alaska [44], and mapped stratigraphic relationships between Quesnellia and the pericratonic belt $[26,45]$ may imply that separation of Stikinia- 


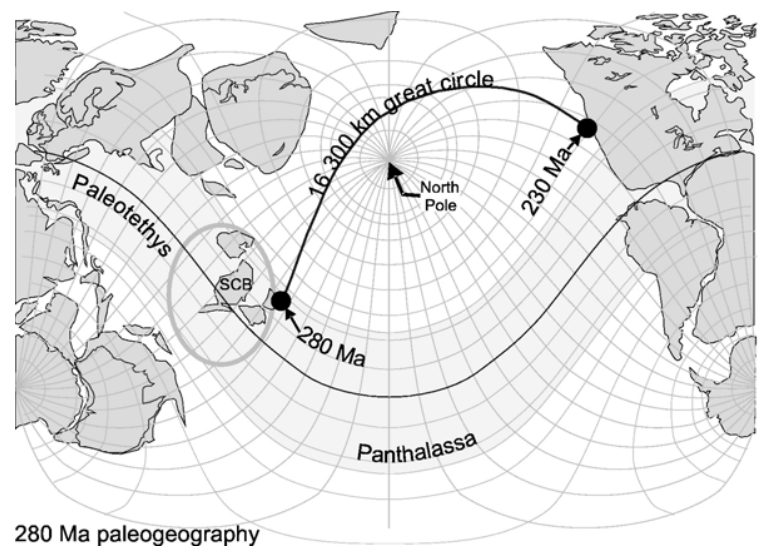

Fig. 4. Paleogeographic map for 280 Ma showing the shortest route between the easternmost Tethyan domain, at left, and the west coast of North America, at right - a $16300 \mathrm{~km}$ long great circle route across Panthalassa. In this and in all subsequent PTP plots the paleogeographic positioning of the main continental blocks (shown in grey) is taken from Stampfli and Borel [78]. Light grey shading indicates the tropical belt. The grey ellipse encloses the South Chinese blocks (SCB) that lie along and define the eastern limit of the Tethyan domain and indicates the region in which we interpret the Cache Creek seamounts to have originated. The seamounts departed the Tethyan domain in the Permian (280 Ma or later) and accreted to the Stikinia-Quesnellia arc at $230 \mathrm{Ma}$. This PTP requires impossibly high translation rates $(>32 \mathrm{~cm} / \mathrm{a})$.

Quesnellia and the pericratonic belt varied along strike and consisted of discontinuous marginal basins.

\subsection{Foreland passive margin}

Non- to weakly metamorphosed Paleozoic to Middle Jurassic shallow water carbonates and deeper water argillaceous sediments, locally underpinned by Meso- and Neoproterozoic clastic and carbonate sequences, dominate the Cordilleran Foreland. The passive margin assemblages can, based on the distribution of Paleozoic carbonates and shales, be divided into an internal or landward carbonate belt (the Rocky Mountain or Mackenzie platform), a medial shale basin (Selwyn basin/ Kechika Trough), and an outer or oceanward carbonate belt (Cassiar platform) (Fig. 1).

Metamorphic rocks of the pericratonic belt overlie the outboard Cassiar platform along a series of east-verging thrust faults [46]. Deformed and metamorphosed Permian strata in the pericratonic hangingwall of the thrust system limits emplacement to the Upper Permian or younger. Triassic conglomerate containing clasts of eclogite, blueschist and other distinct lithologies derived from the pericratonic belt unconformably overlies the Cassiar platform, indicating thrust emplacement in the Triassic. The inner Rocky Mountain-Mackenzie platform was characterized by a starved passive margin with local phosphorite deposition into the Lower Jurassic [47], suggesting that the margin faced an open ocean basin. Inundation of the passive margin by westerlyderived flysch began at about $152 \mathrm{Ma}$ [48], terminating phosphorite deposition and recording structural loading of the North American margin.

\section{Potential Translation Paths}

Utilizing the key constraints provided by the stratigraphic relationships described above, we employ
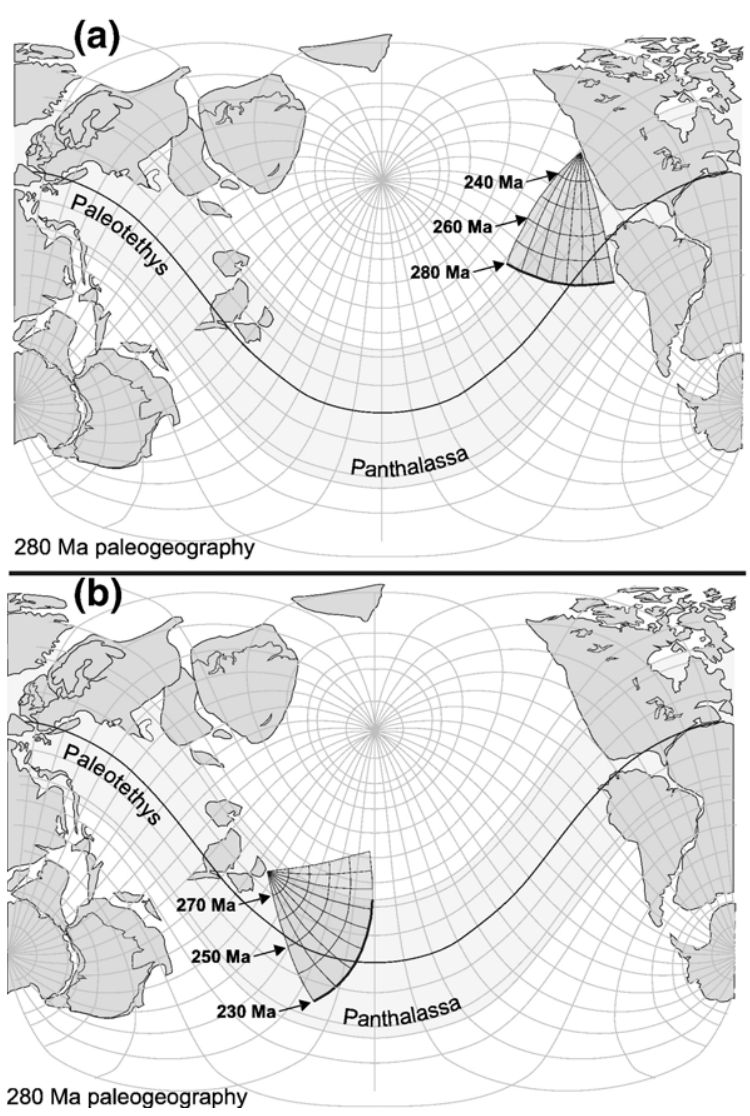

Fig. 5. PTP plots assuming a translation rate of $11 \mathrm{~cm} / \mathrm{a}$ for the period from $280 \mathrm{Ma}$ (soon after the Upper Carboniferous origin of the Cache Creek seamounts) to $230 \mathrm{Ma}$ (the time at which the seamounts accrete to the Stikinia-Quesnellia arc), drawn on a 280 Ma paleogeographic map. (a) PTP plot drawn assuming that the Cache Creek seamounts accrete to arcs along the American margin. In this case the origin of the PTP velocity net represents the point of accretion at $230 \mathrm{Ma}$. Time lines are constructed back through time to $280 \mathrm{Ma}$. The bold $280 \mathrm{Ma}$ time line indicates the range of possible starting points for the Cache Creek seamounts. (b) PTP plot drawn assuming that the Cache Creek seamounts originated within the Tethyan domain. We assume a point of origin for the velocity net at $280 \mathrm{Ma}$ at the eastern edge of the Chinese crustal blocks that lay along the eastern margin of the Paleotethys sea. The bold 230 Ma time line indicates the maximum distance travelled prior to accretion to the Stikinia-Quesnellia arc. 


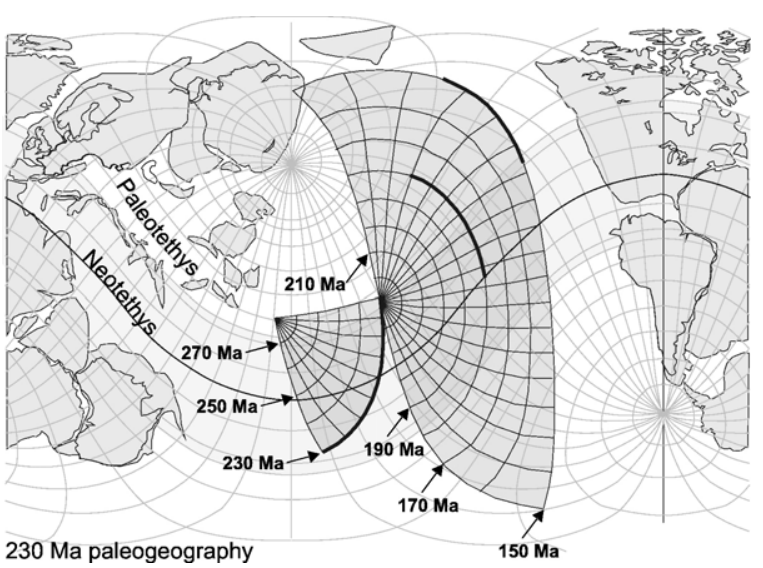

Fig. 6. PTP plot shown on a 230 Ma paleogeographic map assuming a Tethyan origin for the Cache Creek seamounts. The $280 \mathrm{Ma}$ to $230 \mathrm{Ma}$ Cache Creek velocity net is indicated. Note that the Chinese crustal blocks have already migrated to the northeast. We assume accretion of the Cache Creek seamounts to Stikinia-Quesnellia to have occurred within the northernmost tropical belt, and use this as the origin of a 230 to 150 velocity net. Bold portions of the 180 and 150 Ma time lines indicate the range of probable locations of collision of StikiniaQuesnellia with the pericratonic belt-outboard continental platform, and accretion to the North American plate, respectively.

a series of Potential Translation Path (PTP) plots (Figs. 3-6) in order to place limits on the paleogeographic location of the Cache Creek seamounts throughout their translation, accretion, and final incorporation into the Cordilleran accretionary orogen. On PTP plots the Potential Translation Paths of a terrane are indicated as a series of great circles radiating out from an assumed starting location. Small circles perpendicular to the great circles are time lines showing the maximum distance travelled per increment of time (typically 10 million year increments) assuming a set velocity. Therefore, the small circles show the maximum possible distance covered by a terrane from an assumed starting point, given a constant vector of motion over a given period of time. Together the time lines and the translation paths define a velocity net that shows the maximum limits a terrane (or point on a plate) can travel in any given time period (Fig. 3).

The motion of any point on a plate describes a small circle about a pole of rotation (Euler Pole). Only the motion of points located $90^{\circ}$ from the Euler pole describe great circle routes. While the angular speed on any point on a rotating plate is the same (measured in degrees per m.y.), velocity measured in $\mathrm{km}$ per m.y. increases to a maximum $90^{\circ}$ from the Euler pole. By using great circle routes as PTP, we tacitly assume a location on an Euler equator. Translation rates utilized in PTP plots are therefore the maximum possible rates for motions of the plates on which the translating points resided.

Our PTP plots are constructed assuming that plate tectonic rates have not changed appreciably throughout the Phanerozoic and that recent plate velocities are not anomalous. Plate motion models, the most commonly utilized being the NUVEL models, make use of sea floor spreading rates calculated over the past 3 million years as a means of constraining current vectors of plate motion [49]. These models indicate that the current maximum full spreading rate across mid-ocean ridges is about $16 \mathrm{~cm} / \mathrm{a}$ (along a portion of the East Pacific Rise). The global average spreading rate is $4 \mathrm{~cm} / \mathrm{a}$. Convergence rates at subduction zones average $7 \mathrm{~cm} / \mathrm{a}$, with maximum rates of $11 \mathrm{~cm} / \mathrm{a}$ (in the southwest Pacific) [50]. Longer term, though less accurate rates of plate motion calculated using the greater sea floor record of spreading extending back into the Jurassic, and by the use of hotspot tracks assuming a relatively fixed hotspot reference frame, yield similar estimates of rates of plate motion $[51,52]$. Plate motion rates, extending from the present day back to the Jurassic appear, therefore, unchanged, with maximum full spreading rates of about $16 \mathrm{~cm} / \mathrm{a}$ and maximum convergence rates across subduction zones of about $11 \mathrm{~cm} / \mathrm{a}$. In most of our PTP plots we assume average, long term translation rates of $11 \mathrm{~cm} / \mathrm{a}\left(1^{\circ}\right.$ per $\mathrm{m} . \mathrm{y}$.). Though above the average observed spreading and convergence rates, $11 \mathrm{~cm} / \mathrm{a}$ is below the maximum observed spreading rate, and is about the maximum observed rate of convergence. Such a rate, therefore, provides a reasonable means of estimating the possible distance travelled during a given period of time.

Key geological constraints used in constructing PTP plots for the Cache Creek and associated Cordilleran terranes, are that (1) the Cache Creek seamounts originated adjacent to the east margin of the South Chinese crustal blocks that lay along and defined the eastern limit of Tethys; (2) eastward translation of the Cache Creek seamounts away from the Tethyan domain and across Panthalassa began at $280 \mathrm{Ma}$; (3) seamount accretion to Stikinia-Quesnellia occurred at $230 \mathrm{Ma}$; (4) Stikinia-Quesnellia remained at tropical latitudes until about $200 \mathrm{Ma}$; (5) accretion of Stikinia-Quesnellia to the previously combined pericratonic belt-Cassiar platform occurred at $180 \mathrm{Ma}$; and (6) the accreted collage of seamounts, arcs and pericratonic terranes were obducted onto the west margin of the North American plate at approximately their current latitude with respect to the autochthon at $150 \mathrm{Ma}$. We consider these assumptions conservative. Given the overwhelmingly Tethyan nature of the Middle and Upper Permian 
limestones of the Cache Creek terrane, it may be that the seamounts originated within a more central location in Tethys and did not depart from the seaway until or after 260 Ma. Previous workers [16] have postulated that accretion of the seamounts to the magmatic arcs had begun by the end of the Permian. Pre-Middle Triassic seamount accretion may indicate that the Cache Creek seamounts formed a chain that extended some distance east into western Panthalassa. Stikinia-Quesnellia and pericratonic belt are stitched together by $186 \mathrm{Ma}$ [41], some 6 m.y. in advance of our assumed 180 Ma collision. Cessation of the Late Triassic Stuhini-Lewes River arc may record entry of the pericratonic belt into the subduction zone, indicating that collision may have begun even earlier $(\sim 200 \mathrm{Ma})$.

\subsection{Accretion of Cache Creek seamounts to Stikinia-Quesnellia}

If the Stikinia-Quesnellia arc did develop on or immediately adjacent to the western margin of North America, then the Cache Creek seamounts were faced with the immense task of crossing the entire Panthalassan ocean basin prior to accretion (Figs. 2, 4). Given the 50 m.y. window for translation (280 Ma to $230 \mathrm{Ma}$ ), crossing the $>16000 \mathrm{~km}$ wide Panthalassa using the most direct route possible (great circle route from tropical easternmost Tethys to the North American margin) would require a translation rate of $>32 \mathrm{~cm} / \mathrm{a}$. Such a direct translation path results, however, in departure of the seamounts from the tropics in the Middle Permian, and ignores the need to maintain the Cache Creek seamounts at tropical latitudes into the Lower Triassic. A more realistic but significantly longer translation path, maintaining the Cache Creek seamounts at low latitudes throughout the Permian, would require translation velocities of $>40 \mathrm{~cm} / \mathrm{a}$. In the absence of evidence pointing to a substantially different plate tectonic regime prior to $180 \mathrm{Ma}$, translation paths requiring long term plate tectonic rates well in excess of $15 \mathrm{~cm} / \mathrm{a}$ are viewed as untenable.

PTP plots constructed utilizing a translation rate of $11 \mathrm{~cm} / \mathrm{a}$ obliges us to conclude that the Cache Creek seamounts could not have crossed Panthalassa in 50 m.y. (Fig. 4). Either the Stikinia-Quesnellia arc did not develop along the western margin of North America, or the Cache Creek seamounts did not originate in the Tethyan domain. If we assume that Stikinia-Quesnellia was located along the American continental margin, then the Cache Creek seamounts are restricted to having originated within the tropics less than $3000 \mathrm{~km}$ west of the American coast (Fig. 5a). The alternative interpretation is that the Cache Creek seamounts did originate within the Tethyan domain (Fig. 5b), in which case accretion to Stikinia-Quesnellia at 230 Ma must have occurred within western Panthalassa, less than $5000 \mathrm{~km}$ east of the eastern margin of Tethys. Because of the substantial faunal evidence for the Cache Creek seamounts having originated in Tethys, our preferred interpretation has the Cache Creek seamounts accreting to Stikinia-Quesnellia in western Panthalassa. Accretion is assumed to have occurred within the northern hemisphere, based on the paleomagnetic data from Permian strata that place Stikinia-Quesnellia north of the equator at that time.

\subsection{Post-Cache Creek seamount accretion}

We assume that the Cache Creek seamounts accreted to Stikinia-Quesnellia within the northernmost tropics 10000 to $11000 \mathrm{~km}$ west of the nearest portion of the western margin of North America (Fig. 5b). Accretion of the seamounts near the equator or farther south increases the distance to North America. Eastward migration beginning at $230 \mathrm{Ma}$ at $11 \mathrm{~cm} / \mathrm{a}$ brings the Stikinia-Quesnellia arc, with its accreted seamounts, to within 1500 to $2000 \mathrm{~km}$ of the inferred western margin of North America by $150 \mathrm{Ma}$ (Fig. 6); the more southerly the overall 230 to 150 Ma translation path, the shorter the distance to North America. It is, therefore, possible for the Cache Creek seamounts to have accreted to the North American plate, via transport on the Stikinia-Quesnellia arc, by $150 \mathrm{Ma}$ given reasonable rates of translation. The $230 \mathrm{Ma}$ to $150 \mathrm{Ma}$ translation interval was, however, punctuated by the collision of Stikinia-Quesnellia with the previously combined pericratonic belt-outer Cassiar platform at 190 to $180 \mathrm{Ma}$. Assuming a constant $11 \mathrm{~cm} / \mathrm{a}$ rate of eastward translation limits collision to having occurred within central Panthalassa, some 4000 to $6000 \mathrm{~km}$ west of the North American margin (Fig. 6).

\section{Discussion}

It is commonly assumed that the Cache Creek terrane, with its Tethyan fauna, is exotic with respect to autochthonous North America. Most of the other terranes that constitute the Cordilleran orogen are presumed to have originated within or immediately adjacent to the North American continental margin [53]. These two assumptions are, however, mutually exclusive. Interpretation of Stikinia-Quesnellia as a North American marginal arc limits the Cache Creek seamounts to having originated within $3000 \mathrm{~km}$ of the North American margin. Such an American-proximal 
origin is unlikely, as coeval tropical North American carbonate sequences are characterized by a distinctly different faunal assemblage. Offshore (westerly) drift of trade wind-driven tropical ocean currents should have seeded nearby seamounts with American fauna, and yet no such cross-fertilization is observed. Furthermore, interpreting the Cache Creek seamounts as having originated adjacent to the American continental margin would imply that Tethyan fauna were common within Panthalassa and ignores the DUPAL isotopic signature of the Cache Creek basalts. The record of Tethyan terranes outside of Asia is restricted (small volume isolated allochthons in Japan and easternmost Russia), inconsistent with models that require the widespread distribution of Tethyan fauna within Panthalassa. DUPAL mantle is an isotopically distinct mantle reservoir that is enriched and radiogenic [10] and which underlies the Indian ocean region. The DUPAL anomaly is thought to be long-lived, probably having originated in Precambrian time, and likely characterized the Tethyan domain during the Paleozoic and Mesozoic [10]. Thus the DUPAL isotopic signature of the Cache Creek basalts provides an independent verification of the Tethyan origin of the Cache Creek seamounts.

Placing Stikinia-Quesnellia in western Panthalassa allows for the Tethyan origin and DUPAL isotopic character of the Cache Creek seamounts, and better explains the mixed (McCloud) faunal character of Stikinia-Quesnellia. The presence within StikiniaQuesnellia of Tethyan faunal elements as old as Upper Devonian may imply that Stikinia-Quesnellia originated within or immediately adjacent to the Tethys in the Devonian, before migrating east into Panthalassa. Alternatively, if the Cache Creek seamounts did form a chain that extended out into western Panthalassa, the seamounts may have facilitated some limited faunal exchange between the Tethyan domain and the StikiniaQuesnellia arc.

\subsection{Accretionary orogens}

Accretionary orogens are commonly interpreted to develop through the incremental addition of terranes above a convergent plate boundary developed along the margin of a continent [1]. If, however, we accept the faunal evidence of a Tethyan origin for the Cache Creek seamounts, then the concept of the Canadian Cordillera as an accretionary orogen that progressively developed during Devonian to Jurassic subduction beneath North America, as recorded by the Stikinia-Quesnellia arc, is untenable. In our view, the constraints provided by the Cache Creek seamounts indicate that the Canadian
Cordilleran orogen developed in a distinctly different fashion, with accretion events spanning 80 m.y. and having taken place within the western to central portions of the $>16000 \mathrm{~km}$ wide Panthalassa ocean. The Canadian Cordillera did not grow or deform, therefore, through the stepwise addition of terranes to the North American margin, but rather by the arrival at $150 \mathrm{Ma}$ of a major composite superterrane or ribbon continent, previously referred to as Saybia [54,55] incorporating various terranes and lithotectonic assemblages that had been amalgamated elsewhere. Cordilleran evolution was, therefore, a two stage process: (1) accretionary development of a composite ribbon continent within Panthalassa, followed by (2) collision of the composite ribbon continent with the North American plate beginning in the Lower Jurassic.

Shale, argillite and chert of the Selwyn and correlative basin domains separate the outboard Cassiar platform, the eastern most portion of the ribbon continent, from the inboard Mackenzie-Rocky Mountain platform. Interpretation of the Cassiar platform as exotic requires the presence of a cryptic suture within or along the margins of the Selwyn basin. Locally the inboard margin of the Selwyn basin is characterized by a major foreland-verging thrust fault, such as the Dawson Fault in Yukon (Fig. 1). In most places, however, the inboard and outboard margins of Selwyn basin have been interpreted as facies changes [56]. How such a significant tectonic boundary could be cryptic remains unclear $[54,55]$, but the answer may lie in resolving the significant post-150 Ma translations that have occurred within the orogen. Paleomagnetic data implies that large portions of the orogen underwent significant midCretaceous southerly displacements [57], coeval with fold and thrust belt formation within the foreland, widespread dextral strike-slip faulting and voluminous granitic magmatism as far inboard as the eastern limit of Selwyn basin [58]. Paleomagnetic data from Late Cretaceous strata require significant northward translations, relative to the autochthon $[59,60]$ coeval with fold and thrust belt formation in the foreland and oroclinal buckling of the ribbon continent in Alaska [55].

\subsection{Panthalassa}

In crossing Panthalassa, the Cache Creek seamounts first collided with and accreted to the StikiniaQuesnellia arc. The arc then subsequently collided with the previously combined pericratonic belt-Outer Carbonate Platform. In both instances, collision was preceded by arc magmatism on Stikinia-Quesnellia, indicating that it was subduction beneath this arc, first of 
the slab on which the Cache Creek seamounts lay, and subsequently of the slab that connected to the pericratonic belt, that led inexorably to the collisions. The implication is that subduction occurred within Panthalassa, far removed from the margins of the bordering Pangea supercontinent (Fig. 7). Panthalassan tectonics, with its internal arcs and subduction zones, was, therefore, significantly different from the tectonic setting of our Pacific Ocean basin, with its geometry of circum-oceanic (Ring of Fire) outward dipping subduction zones fed by a central spreading centre.
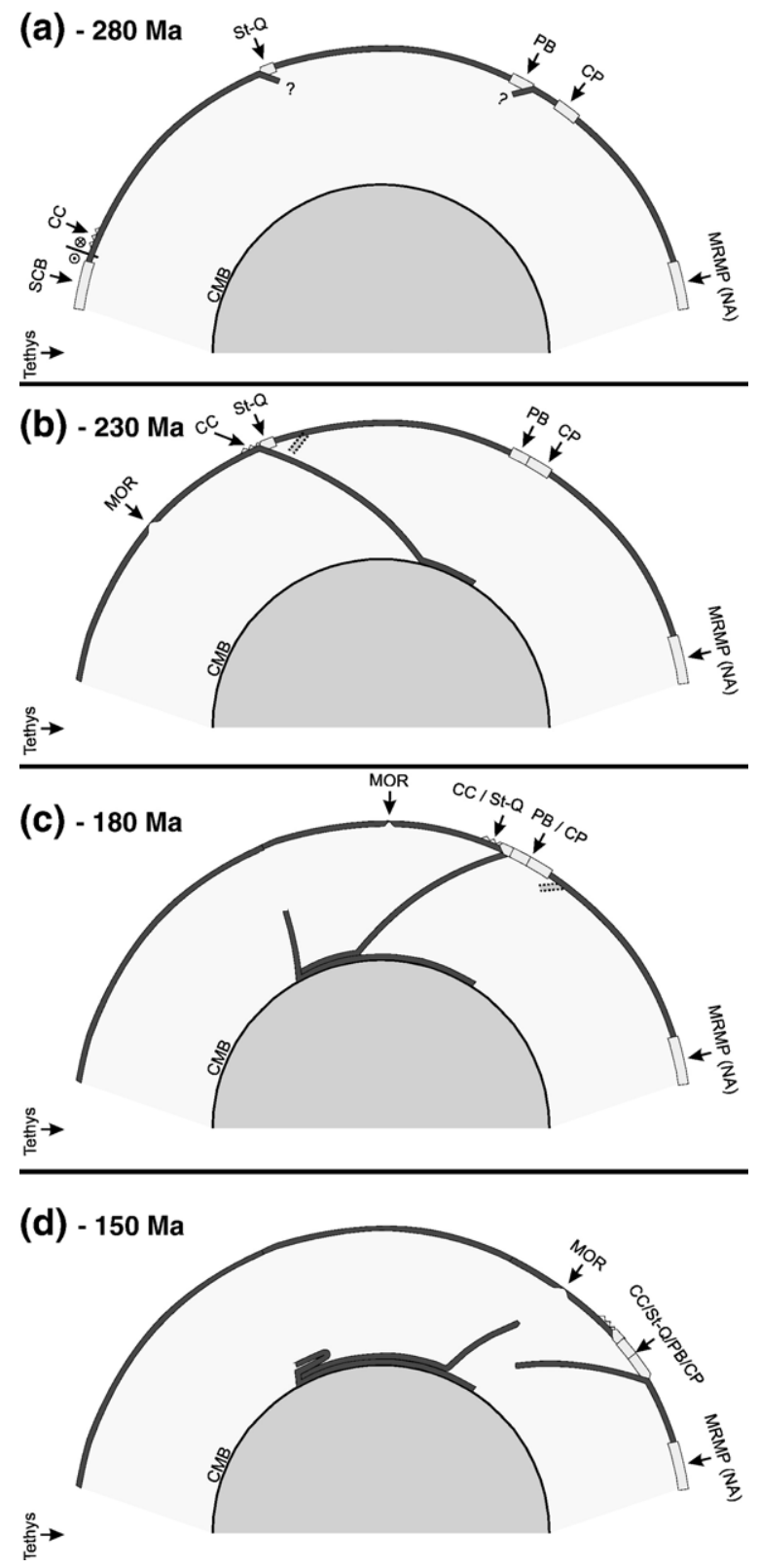

The Pacific Ocean is the post-Pangean remnant of Panthalassa. The basin is host to a number of significant hotspots, most notably the Hawaiian. Most of these hotspots appear to tap into a deep seated mantle source consisting, in some models, of deeply subducted oceanic slabs $[61,62]$. In addition the region is host to a "superswell" of anomalously hot, seismically slow mantle, and a related geoid high of over $600 \mathrm{~m}$ [63]. A mid-Cretaceous superplume event centred in the Pacific basin $[64,65]$ gave rise to voluminous plume related oceanic plateau and seamounts (e.g. Ontong-Java). The magmatic flux at mid-ocean ridges was 15 to $30 \%$ higher at that time [66] due to increased mantle

Fig. 7. Scaled cross-sections of earth depicting, via sequential diagrams at 280 (a), 230 (b), 180 (c) and $150 \mathrm{Ma}$ (d), the translation of the Cache Creek seamounts (CC) across Panthalassa in a fixed North America reference frame. $100 \mathrm{~km}$ thick oceanic lithosphere in dark grey; continental lithosphere, magmatic arcs and seamounts shown in light grey (slightly exaggerated thickness). A simplified mantle is employed (no upper or lower mantle) that ends down against the Core Mantle Boundary (CMB). Oceanic lithosphere is assumed to subduct directly to the $\mathrm{CMB}$ with preservation of line length (no internal strain). Subducted lithosphere is balanced by the growth of new oceanic lithosphere at Mid-Ocean Ridges (MOR). (a) $280 \mathrm{Ma}-$ The CC seamounts are assumed to originate immediately east of the South China crustal blocks (SCB) which form the east limit of the Tethys. A transform fault is shown separating the SCB from oceanic crust underpinning the seamounts in order to facilitate the translation of old oceanic crust past the SCB. Devonian to Permian arc rocks indicate that subduction was ongoing beneath the Stikinia-Quesnellia $\operatorname{arc}(\mathrm{ST}-\mathrm{Q})$ and the pericratonic belt (PB), although the polarity of subduction is, in both cases, poorly constrained. West-dipping subduction facilitates accretion of the PB and CP, but earlier eastdipping subduction is probably required to explain the history of $\mathrm{PB}$ arc magmatism and terrane migration. We assume ongoing eastdipping subduction beneath the west side of St-Q facilitating eastward translation of the Cache Creek seamounts. The locations of the PB and Outer Cassiar continental platform (CP) are conjectural - it may be that the PB was much more closely aligned with St-Q (discussed in text). St-Q may have originated farther east than shown, as 280 to $230 \mathrm{Ma}$ subduction beneath St-Q may have resulted in westward migration of the arc due to roll back of the subducting plate. (b) $230 \mathrm{Ma}$ - Accretion of CC seamounts to St-Q. A change in subduction polarity at this point in time to east-dipping subduction beneath the east margin of St-Q (dashed grey slab shows incipient subduction) facilitates subsequent eastward migration of St-Q. The flipping of subduction polarity is not thought to have been a result of seamount accretion. Oroclinal buckling of the St-Q arc, perhaps in response to seamount accretion [16] may explain the polarity flip. (c) $180 \mathrm{Ma}$ - Termination of eastward translation of CC/St-Q by accretion to the previously amalgamated $\mathrm{PB} / \mathrm{CP}$. Initiation of subduction beneath the eastern margin of the resulting composite ribbon continent (dashed grey slab shows incipient subduction), consisting of $\mathrm{CC} / \mathrm{St}-\mathrm{Q} / \mathrm{PB} / \mathrm{CP}$, explains its subsequent eastward migration. (d) $150 \mathrm{Ma}$ - Subduction beneath the eastern margin of the composite ribbon continent brings it into proximity with continental lithosphere of the lower plate North American margin (MRMP). 
temperature [67]. The mid-Cretaceous sea level high and greenhouse climate may have been related environmental effects of the superplume. The superplume event was coeval with the Cretaceous Normal Superchron, pointing to a deep seated (core-mantle boundary) origin for the superplume [64,65].

The origin of the long-lived positive thermal anomaly in the Pacific may lie in the vast volume of Panthalassan oceanic lithosphere subducted during the transit of the Cache Creek seamounts from Tethys to North America (Fig. 7). Thermal modeling of subducted slabs [68] suggests that they can penetrate intact to the core-mantle boundary where they would give rise to "normal" hotspots along the edges of the slabs. Blanketing of the core-mantle boundary by subducted slabs is interpreted to result in an increased temperature gradient at the core-mantle boundary, resulting in increased heat transfer from the core to the mantle. The heat transferred to the lowermost mantle is then trapped beneath the cold slabs which, because of their high viscosity must be conductively heated. The consequence is a long term build-up of heat beneath the slabs that eventually gives rise to a superplume event [68]. If all the oceanic lithosphere subducted during the transit of the Cache Creek seamounts sank to the Core Mantle Boundary, the result would have been the development, between $280 \mathrm{Ma}$ and $150 \mathrm{Ma}$, of a substantial slab blanket on the sub-Pacific portion of the core (Fig. 7). We suggest that it was this blanket of subducted Panthalassan oceanic lithosphere which gave rise to the Pacific hotspots (from along the margins of the subducted slabs), and spawned the mid-Cretaceous superplume event (and the Cretaceous Normal Superchron), the remnant of which is the Pacific Superswell. Our model, which places the Cordilleran Triassic-Jurassic subduction system far removed from the west margin of Pangea, within Panthalassa, is at variance with models $[69,70]$ which seek to explain the Pacific and African superswells as products of landward-dipping, circumsuper continental subduction beneath Pangea.

\subsection{Pangea break-up}

Did the Cordilleran accretionary orogen play a role in the break-up of Pangea [71, 72]? The oldest recognized magnetic anomaly (M25-155 Ma) in the western Central Atlantic Ocean is separated from the continental margin by $\sim 500 \mathrm{~km}$ of older oceanic crust. Magnetic anomalies in oceanic lithosphere offshore of Morocco in the eastern Central Atlantic are of Toarcian age (175-183 Ma) [73], consistent with a Lower Jurassic transition from rift stage evaporites to drift stage open marine carbonates along the North American continental margin following about 20 m.y. of rifting [74].

Thermal modeling suggests that supercontinents can insulate the mantle, giving rise to a gradual increase in the temperature of the underlying asthenosphere [75]. Upwelling of abnormally warm mantle may, therefore, have had a role in the break-up of Pangea. The rift to drift transition during Pangea break-up was not, however, accompanied by massive, plume related magmatism along the length of the margin, suggesting that the role of the sub-Pangea mantle in initiating supercontinent break-up was spatially restricted. In addition, intra-Tethyan subduction cooled eastern Pangea, and 100 m.y. (the maximum lifespan of Pangea) is not a long time for significant insulation.

Explanation of Pangea break-up may, therefore, lie in the far field stress that was acting upon the supercontinent. Collision of Stikinia-Quesnellia with its previously accreted Cache Creek seamounts, and the Pericratonic Belt / Cassiar platform occurred between 190 and $180 \mathrm{Ma}$, and was followed by the initiation of westdipping subduction beneath the east margin of the composite ribbon continent. Closure of the basin intervening between the composite ribbon continent and the west margin of North America was accommodated by westward subduction, as indicated by arc magmatism on the ribbon continent versus a passive margin setting for continued sedimentation along the ancient western coast of North America. The oceanic lithosphere subducting beneath the ribbon continent was, therefore, continuous with and part of the same plate that contained Pangea (Fig. 7). Initiation of west-dipping subduction was coincident with the rift to drift transition in the Central Atlantic. Slab pull exerted by this subducting slab may, therefore, have been responsible for a tensile stress field that ultimately caused failure and break-up of Pangea. Supporting this contention is that closure of the basin lying west of North America, and docking of the ribbon continent with the North American plate at 150 Ma was coeval with a dramatic slowing of the rate of spreading within the Atlantic domain, from between 2 to $2.5 \mathrm{~cm} / \mathrm{a}$ half spreading rate, to 0.5 to $1.0 \mathrm{~cm} / \mathrm{a}[76,77]$.

\section{Conclusions}

Middle to Upper Triassic accretion of the Tethyan Cache Creek seamounts to Stikinia-Quesnellia, and Lower Jurassic collision of Stikinia-Quesnellia with the combined pericratonic belt-Cassiar platform, occurred $>10000 \mathrm{~km}$ and $>4000 \mathrm{~km}$ west of autochthonous North America, respectively. Most of the Cordilleran orogen is, therefore exotic with respect to North America. The 
development of the Cordilleran accretionary orogen was not, therefore, the result of sequential terrane accretion along the continent margin, but was instead a two stage process and resulted in significant growth of the North American continent. Stage one involved the $230 \mathrm{Ma}$ to $150 \mathrm{Ma}$ accretionary amalgamation of a ribbon continent within central to western Panthalassa. Stage two, from $150 \mathrm{Ma}$ to $55 \mathrm{Ma}$, consisted of collision, margin parallel translation and final coalescence of the composite ribbon continent with North America. Evolution and development of the Canadian Cordillera implies that accretionary orogens may, therefore, involve an off shore amalgamation stage that may take place far removed from the autochthonous continent.

The Panthalassa ocean basin was significantly different from our current Pacific Ocean basin, being characterized by a number of internal subduction zones in which large volumes of oceanic lithosphere were consumed. Sinking of these slabs to the Core Mantle Boundary may have insulated the core beneath the Pacific giving rise to the mid-Cretaceous Pacific Superplume and the related Cretaceous Normal Superchron, and explaining the origin and geochemistry of the Pacific hotspots.

Westward subduction of oceanic lithosphere, starting at $180 \mathrm{Ma}$, that was part of the same plate as Pangea, closed the ocean basin separating the supercontinent from the terranes amalgamated within Panthalassa. Far field tensile stress attributable to the pull of the subducting slab pulled Pangea apart, initiating the dispersal phase of the supercontinent cycle. Closure of the basin at $150 \mathrm{Ma}$ terminated the slab pull induced stress and resulted in a drastic reduction in the rate of spreading within the growing Atlantic Ocean.

PTP plots provide a simple and efficient means of testing suggested paleogeographic reconstructions. Faunal constraints, like those provided by the Cache Creek terrane, can aid in the recognition of longitudinal and latitudinal displacements. Such faunal constraints are, however, unavailable for much of earth history, limiting our ability to test most proposed paleogeographic reconstructions. The use of PTP plots, together with assumptions regarding acceptable plate tectonic speed limits, can, however, help to distinguish between plausible and implausible models of continental assembly and dispersal.

\section{Acknowledgements}

Much of the research reported here was conducted while STJ was Professeur Invité at the Musée cantonal de géologie, Etat de Vaud, Switzerland, and a recipient of the Fondation Herbrette Science Award at the
University of Lausanne, Switzerland. Additional support included a National Science and Engineering Research Council Discovery Grant to STJ. Dante Canil is thanked for comments and discussion. We benefited from discussions with and encouragement by Gérard Stampfli. In addition, Gérard critically read and commented on the manuscript. An anonymous reviewer significantly improved the manuscript. Rob D. van der Hilst is thanked for his efforts as Editor.

\section{References}

[1] A.M.C. Sengor, B.A. Natalin, Turkic-type orogeny and its role in the making of the continental crust, Annual Review of Earth and Planetary Sciences 24 (1996) 263-337.

[2] P.A. Cawood, Terra Australis Orogen: Rodinia breakup and development of the Pacific and Iapetus margins of Gondwana during the Neoproterozoic and Paleozoic, Earth-Science Reviews 69 (2005) 249-279.

[3] J.W.H. Monger, Plate tectonics and northern Cordilleran geology: an unfinished revolution, Geoscience Canada 24 (1997) 189-198.

[4] P.J. Coney, D.L. Jones, J.W.H. Monger, Cordilleran suspect terranes, Nature 288 (1980) 329-333.

[5] J.W.H. Monger, C.A. Ross, Distribution of fusulinaceans in the western Canadian Cordillera, Canadian Journal of Earth Sciences 8 (1971) 259-278.

[6] J. English, Convergent Margin Tectonics in the North American Cordillera: Implications for Continental Growth and Orogeny, Ph.D., University of Victoria, 2004.

[7] A.D. Smith, R. St J. Lambert, Nd, Sr, and $\mathrm{Pb}$ isotopic evidence for contrasting origins of late Paleozoic volcanic rocks from the Slide Mountain and Cache creek terrances, south-central British Columbia, Canadian Journal of Earth Sciences 32 (1994) 447-459.

[8] J.M. English, M.G. Mihalynuk, S.T. Johnston, F.A.M. Devine, Atlin TGI Part III: Geology and petrochemistry of mafic rocks within the northern Cache Creek terrane and tectonic implications, Geological Fieldwork 2001 Paper 2002-1, B.C. Ministry of Energy and Mines, Victoria, BC, 2002, pp. 19-30.

[9] J.W.H. Monger, Upper Paleozoic rocks of the northwestern British Columbia, Paper 77-1A, Geological Survey of Canada (1977) 255-262.

[10] S.R. Hart, A large-scale isotope anomaly in the southern hemisphere mantle, Nature 309 (1984) 753-757.

[11] H. Gabrielse, Late Paleozoic and Mesozoic terrane interactions in north-central British Columbia, Canadian Journal of Earth Sciences 28 (1991) 947-957.

[12] G.D.J. Stanley, Late Paleozic and early Mesozoic reef-building organisations and paleogeography: the Tethyan-North American connection, Courier Forschungsinstitut Senckenberg 172 (1994) 69-75.

[13] M.J. Orchard, L.C. Struik, L. Rui, E.W. Bamber, B. Mamet, H. Sano, H. Taylor, Palaeontological and biogeographical constraints on the Carboniferous to Jurassic Cache Creek terrane in central British Columbia, Canadian Journal of Earth Sciences 38 (2001) 551-578.

[14] F. Cordey, N. Mortimer, P. Dewever, J.W.H. Monger, Significance of Jurassic radiolarians from the Cache Creek terrane, British Columbia, Geology 15 (1987) 1151-1154.

[15] B. Wernicke, D.W. Klepacki, Escape hypothesis for the Stikine block, Geology 16 (1988) 461-464. 
[16] M.G. Mihalynuk, J. Nelson, L.J. Diakow, Cache Creek terrane entrapment: oroclinal paradox within the Canadian Cordillera, Tectonics 13 (2) (1994) 575-595.

[17] R.G. Anderson, A stratigraphic, plutonic, and structural framework for the Iskut River map area, northwestern British Columbia, Current Research Part E Paper 89-1E, Geological Survey of Canada, 1989, pp. 143-151.

[18] D.A. Brown, J.M. Logan, M.H. Gunning, M.J. Orchard, W.E. Bamber, Stratigraphic evolution of the Paleozoic Stikine assemblage in the Stikine and Iskut rivers area, northwestern British Columbia, Canadian Journal of Earth Sciences 28 (1991) 958-972.

[19] M.G. Mihalynuk, M.T. Smith, K.D. Hancock, S. Dudka, Regional and economic geology of the Tulsequah River and Glacier areas (104K/12 and 13 ), Geological Fieldwork 1993 Paper 1994-1, 1994, pp. 321-342.

[20] C.J.R. Hart, A transect across northern Stikinia: geology of the northern Whitehorse map area, southern Yukon Territory (105D/ 13-16), Exploration and Geological Services Division, Indian and Northern Affairs Canada, Yukon, 1997, p. 112.

[21] W.C. McClelland, G.E. Gehrels, S.D. Samson, P.J. Patchett, Structural and geochronologic relations along the western flank of the Coast Mountains batholith: Stikine River to Cape Fanshaw, central southeastern Alaska, Journal of Structural Geology 14 (1992) 475-489

[22] J.M. Logan, V.M. Koyanagi, Geology and Mineral Deposits of the Galore Creek Area $(104 \mathrm{G} / 3,4)$ Bulletin, vol. 92, B.C. Ministry of Energy, Mines and Petroleum Resources, Victoria BC, 1994, p. 95

[23] E.S. Carter, M.J. Orchard, C.A. Ross, J.R.P. Ross, P.L. Smith, H.W. Tipper, Paleontological signatures of terranes, in: H. Gabrielse, C.J. Yorath (Eds.), Geology of the Cordillera Orogen in Cananda, Part B, The Geology of North America, vol. G-2, Geological Society of America, Denver CO, 1992, pp. 28-38.

[24] E.L. Miller, M.M. Miller, C.H. Stevens, J.E. Wright, R. Madrid, Late Paleozoic paleogeographic and tectonic evolution of the western U.S. Cordillera, in: B.C. Burchfiel, P.W. Lipman, M.L. Zoback (Eds.), The Cordilleran Orogen: Conterminous U.S., vol. G3, Geological Society of America, Denver CO, 1992, pp. 57-106.

[25] M.M. Miller, Dispersed remnants of a northeast Pacific fringing arc: Upper Paleozoic terranes of Permian McCloud faunal affinity, western U.S. Tectonics 6 (1987) 807-830.

[26] P. Erdmer, J.M. Moore, L. Heaman, R.I. Thompson, K.L. Daughtry, R.A. Creaser, Extending the ancient margin outboard in the Canadian Cordillera: record of Proterozoic crust and Paleocene regional metamorphism in the Nicola horst, southern British Columbia, Canadian Journal of Earth Sciences 39 (2002) 1605-1623.

[27] M.J. Orchard, An overview of terrane conodonts; what do the tell us? Annual Meeting, vol. 32, Geological Society of America, Denver CO, 2000, p. 60.

[28] R.P. Reid, D.J. Tempelman-Kluit, Upper Triassic Tethyan-type reefs in the Yukon, Bulletin of Canadian Petroleum Geology 35 (1987) 316-332.

[29] G.D. Stanley, B. Senowbari-Daryan, Upper Triassic reef fauna from the Quesnel terrane, central British Columbia, Canada, Journal of Paleontology 73 (1999) 787-802.

[30] E. Irving, P.J. Wynne, Chapter 3, Paleomagnetism: Review and Tectonic Implications, in: H. Gabrielse, C.J. Yorath (Eds.), Geology of the Cordilleran Orogen in Canada, vol. G-2, Geological Society of America, Denver, Colorado, 1991, pp. 61-86.
[31] T.A. Vandall, H.C. Palmer, Canadian Cordilleran displacement: Paleomagnetic results from the Early Jurassic Hazelton Group, Terrane-I, British Columbia, Canada, Geophysical Journal International 103 (1990) 609-619.

[32] J.W.H. Monger, Upper Paleozoic rocks of the Atlin terrane, Geological Survey of Canada, 1975, p. 63

[33] M.G. Mihalynuk, S.T. Johnston, J.M. English, F. Cordey, M.E. Villeneuve, L. Rui, M.J. Orchard, Atlin TGI, Part II: Regional geology and mineralization of the Nakina area (NTS 104N/2W and 3), Geological Fieldwork 2002 Paper 2003-1, B.C. Ministry of Energy and Mines, Victoria, BC, 2003, pp. 9-37.

[34] E.D. Ghent, P. Erdmer, D.A. Archibald, M.Z. Stout, Pressuretemperature and tectonic evolution of Triassic lawsonitearagonite blueschists from Pinchi Lake, British Columbia, Canadian Journal of Earth Sciences 33 (1996) 800-810.

[35] D.A. Archibald, P. Schiarizza, J.I. Garver, ${ }^{40} \mathrm{Ar} /{ }^{39} \mathrm{Ar}$ Evidence for the Age of Igneous and Metamorphic Events in the Bridge River and Shulaps Complexes, Southwestern British Columbia, in: W.R. Smyth (Ed.), Geological Fieldwork 1990; a Summary of Field Activities and Current Research, vol. 1991-1, British Columbia Ministry of Energy, Mines and Petroleum Resources, Victoria BC, 1991, pp. 75-83.

[36] F. Cordey, S.P. Gordey, M.J. Orchard, New biostratigraphic data from the northern Cache Creek terrane, Teslin map area, southern Yukon, Current Research, Part E Paper 91-1E, Geological Survey of Canada, 1991, pp. 67-76.

[37] M.G. Mihalynuk, P. Erdmer, E.D. Ghent, F. Cordey, D Archibald, R.M. Friedman, G.G. Johannson, Coherent French Range blueschists: subduction to exhumation in $<2.5$ Myrs? Geological Society of America Bulletin 116 (2004) 910-922.

[38] J.K. Mortensen, Pre-mid-Mesozoic tectonic evolution of the YukonTanana terrane, Yukon and Alaska, Tectonics 11 (1992) 836-853.

[39] P. Erdmer, E.D. Ghent, D.A. Archibald, M.Z. Stout, Paleozoic and Mesozoic high-pressure metamorphism at the margin of ancestral North America in central Yukon, Geological Society of America Bulletin 110 (1998) 615-629.

[40] J.L. Nelson, The Sylvester Allochthon: upper Paleozoic marginal-basin and island-arc terranes in northern British Columbia, Canadian Journal of Earth Sciences 30 (1993) 631-643.

[41] S.T. Johnston, P. Erdmer, Hot-side-up aurole in southwest Yukon and limits on terrane assembly of the northern Canadian Cordillera, Geology 23 (1995) 419-422.

[42] S.D. Samson, W.C. McClelland, P.J. Patchett, G.E. Gehrels, R.G. Anderson, Evidence from neodymium isotopes for mantle contributions to Phanerozoic crustal genesis in the Canadian Cordillera, Nature 337 (1989).

[43] J.M. MacKenzie, D. Canil, S.T. Johnston, J. English, M.G. Mihalynuk, B. Grant, First evidence for ultrahigh-pressure garnet peridotite in the North American Cordillera, Geology 33 (2005) $105-108$.

[44] V.L. Hansen, Yukon-Tanana terrane: a partial acquittal, Geology 18 (1990) 365-369.

[45] C.F. Roots, J.L. Nelson, R.-L. Simard, M.G. Mihalynuk, T.A. Harms, R. Friedman, L. Heaman, Continental fragments, midPaleozoic arcs and overlapping Triassic sedimentation in the Yukon-Tanana terrane of northern British Columbia and southern Yukon, in: M. Colpron, J.L. Nelson (Eds.), Paleozoic Evolution and Metallogeny of Pericratonic Terranes at the Ancient Pacific Margin of North America, Canadian and Alaskan Cordillera, Special Paper, vol. 45, Geological Association of Canada, St. John's, NFLD, 2006, pp. 153-177. 
[46] S.P. Gordey, Structure and terrane relationships of Cassiar and Kootenay (Yukon-Tanana) terranes, teslin map area, southern Yukon Territory, Geological Survey of Canada (1995) 135-140.

[47] T.P. Poulton, J.D. Aitken, The Lower Jurassic phosphorites of southeastern British Columbia and terrane accretion to western North America, Canadian Journal of Earth Sciences 26 (1989) 1612-1616.

[48] G.M. Ross, P.J. Patchett, M. Hamilton, L. Heaman, P.G. DeCelles, E. Rosenberg, M.K. Giovanni, Evolution of the Cordilleran orogen (southwestern Alberta, Canada) inferred from detrital mineral geochronology, geochemistry, and $\mathrm{Nd}$ isotopes in the foreland basin, Geological Society of America Bulletin 117 (2005) 747-763.

[49] C. DeMets, R.G. Gordon, D.F. Argus, S. Stein, Current plate motion, Geophysical Journal International 101 (1990) 425-478.

[50] R.G. Gordon, The plate tectonic approximation: Plate nonrigidity, diffuse plate boundaries, and global plate reconstructions, Annual Reviews in Earth and Planetary Sciences 26 (1998) 615-642.

[51] D.C. Engebretson, A. Cox, R.G. Gordon, Relative Motions between Oceanic and Continental Plates in the Pacific Basin, Geological Society of America, Denver, Colorado, 1985, 59 pp.

[52] D.C. Engebretson, M.A. Richards, 180 million years of subduction, GSA Today 2 (1992) 93-100.

[53] H. Gabrielse, C.J. Yorath, Tectonic Synthesis, in: H. Gabrielse, C.J. Yorath (Eds.), Geology of the Cordilleran Orogen in Canada, vol. G-2, Geological Society of America, Denver, Colorado, 1991, pp. 677-705.

[54] K. Gladwin, S.T. Johnston, Mid-Cretaceous pinning of accreted terranes to miogeoclinal assemblages in the northern Cordillera: Irreconcilable with paleomagnetic data?, in: Cordilleran Paleogeography, J. Haggert, R.J. Enkin, (Eds.) Special, Paper, pp., Geological Association of Canada, St. John's NFLD, in press.

[55] S.T. Johnston, The great Alaskan terrane wreck: reconciliation of paleomagnetic and geological data in the northern Cordillera, Earth and Planetary Science Letters 193 (2001) 259-272.

[56] S.P. Gordey, R.G. Anderson, Evolution of the Northern Cordilleran miogeocline, Nahanni Map Area (1051), Yukon and Northwest Territories, Geological Survey of Canada, Ottawa, ON, 1993, 214 pp.

[57] R.J. Enkin, J.B. Mahoney, J. Baker, J. Riesterer, M.L. Haskin, Deciphering shallow paleomagnetic inclinations: 2. Implications from Late Cretaceous strata overlapping the Insular/Intermontane Superterrane boundary in the southern Canadian Cordillera, Journal of Geophysical Research-Solid Earth 108 (2003).

[58] S.T. Johnston, Large scale coast-parallel displacements in the Cordillera: a granitic resolution to a paleomagnetic dilemma? Journal of Structural Geology 21 (1999) 1103-1108.

[59] S.T. Johnston, P.J. Wynne, D. Francis, C.J.R. Hart, R.J. Enkin, D.C. Engebretson, Yellowstone in Yukon: the Late Cretaceous Carmacks Group, Geology 24 (1996) 997-1000.

[60] P.J. Wynne, R.J. Enkin, J. Baker, S.T. Johnston, C.J.R. Hart, The Big Flush - Paleomagnetic signature of a 70 Ma regional hydrothermal event in displaced rocks of the northern Canadian Cordillera, Canadian Journal of Earth Sciences 35 (1998) 657-671.

[61] A.W. Hofmann, Mantle geochemistry: the message from oceanic volcanism, Nature 385 (1997) 219-229.
[62] C. Chauvel, A.W. Hofmann, P. Vidal, HIMU-EM: the French Polynesian connection, Earth and Planetary Science Letters 110 (1992) 99-119.

[63] M. McNutt, A. Judge, The superswell and mantle dynamics beneath the south Pacific, Science 248 (1990) 969-975.

[64] R.L. Larson, Latest pulse of Earth: evidence for a mid-Cretaceous superplume, Geology 19 (1991) 547-550.

[65] R.L. Larson, P. Olsen, Mantle plumes control magnetic reversal frequency, Earth and Planetary Science Letters 107 (1991) 437-447.

[66] J.-P. Cogné, E. Humler, Temporal variation of oceanic spreading and crustal production rates during the last $180 \mathrm{My}$, Earth and Planetary Science Letters 227 (2004) 427-439.

[67] E. Humler, C. Langmuir, V. Daux, Depth versus age: new perspectives from the chemical compositions of ancient crust, Earth and Planetary Science Letters 173 (1999) 7-23.

[68] E. Tan, M. Gurnis, L.J. Han, Slabs in the lower mantle and their modulation of plume formation, Geochemistry Geophysics Geosystems 3 (2002) article no. 1067.

[69] C.G. Chase, D.R. Sprowl, The modern geoid and ancient plate boundaries, Earth and Planetary Science Letters 62 (1983) 314-320.

[70] W.J. Collins, Slab pull, mantle convection, and Pangaean assembly and dispersal, Earth and Planetary Science Letters 205 (2003) 225-237.

[71] P.J. Coney, Cordilleran tectonic transitions and motion of the North American plate, Nature 233 (1971) 462-465.

[72] P.J. Coney, Cordilleran tectonics and North America plate motion, American Journal of Science 272 (1972) 603-628.

[73] C.W. Steiner, A. Hobson, P. Favre, G.M. Stampfli, J. Hernandez, The Mesozoic sequence of Fuerteventura (Canary islands): witness of an Early to Middle Jurassic sea-floor spreading in the Central Atlantic, Geological Society of America Bulletin 110 (1998) 1304-1317.

[74] C.E. Keen, B.D. Longarevic, I. Reid, J. Woodside, R.T. Haworth, H. Williams, Tectonic and geophysical overview; Chapter 2, in: M.J. Keen, G.L. Williams (Eds.), Geology of the Continental Margin of Eastern Canada, The Geology of North America, vol. VI-1, Geological Society of America, Denver, 1990, pp. 31-85.

[75] M. Gurnis, Large-scale mantle convection and the aggregation and dispersal of supercontinents, Nature 332 (1988) 695-699.

[76] K.D. Klitgord, H. Schouten, Plate kinematics of the Central Atlantic, in: P.R. Vogt, B.E. Tucholke (Eds.), The Geology of North America - an Overview, M - The Western North Atlantic Region, Geological Society of America, Denver, 1986, pp. 351-378.

[77] P.R. Vogt, B.E. Tucholke, North Atlantic Ocean basin; aspects of geologic structure and evolution, in: A.W. Bally, A.R. Palmer (Eds.), The Geology of North America - an Overview, A - Introduction, Geological Society of America, Denver, 1989, pp. 53-80.

[78] G.M. Stampfli, G.D. Borel, A plate tectonic model for the Paleozoic and Mesozoic constrained by dynamic plate boundaries and restored synthetic oceanic isochrons, Earth and Planetary Science Letters 196 (2002) 17-33.

[79] T.H. Torsvik, M.A. Smethurst, Plate tectonic modelling: virtual reality with GMAP, Computers and Geosciences 25 (1999) 395-402. 